\title{
Amyloid imaging in the differential diagnosis of dementia: review and potential clinical applications
}

\author{
Robert Laforce Jr*and Gil D Rabinovici
}

\begin{abstract}
In the past decade, positron emission tomography (PET) with carbon-11-labeled Pittsburgh Compound $B(P I B)$ has revolutionized the neuroimaging of aging and dementia by enabling in vivo detection of amyloid plaques, a core pathologic feature of Alzheimer's disease (AD). Studies suggest that PIBPET is sensitive for AD pathology, can distinguish $A D$ from non-AD dementia (for example, frontotemporal lobar degeneration), and can help determine whether mild cognitive impairment is due to AD. Although the short half-life of the carbon-11 radiolabel has thus far limited the use of PIB to research, a second generation of tracers labeled with fluorine-18 has made it possible for amyloid PET to enter the clinical era. In the present review, we summarize the literature on amyloid imaging in a range of neurodegenerative conditions. We focus on potential clinical applications of amyloid PET and its role in the differential diagnosis of dementia. We suggest that amyloid imaging will be particularly useful in the evaluation of mildly affected, clinically atypical or early age-at-onset patients, and illustrate this with case vignettes from our practice. We emphasize that amyloid imaging should supplement (not replace) a detailed clinical evaluation. We caution against screening asymptomatic individuals, and discuss the limited positive predictive value in older populations. Finally, we review limitations and unresolved questions related to this exciting new technique.
\end{abstract}

\section{Introduction}

Positron emission tomography (PET) with amyloid ligands has revolutionized neuroimaging of aging and dementia

${ }^{*}$ Corresponding author: rlaforce@memory.ucsf.edu

Memory and Aging Center, Department of Neurology, University of California San Francisco, 350 Parnassus Avenue, Suite 905, San Francisco, CA 94143, USA in the past decade by enabling the detection and quantification of amyloid plaques, a core pathologic feature of Alzheimer's disease (AD) [1]. The first specific tracer for amyloid-beta $(A \beta)$ applied in human studies was carbon-11 $\left({ }^{11} \mathrm{C}\right)$-labeled Pittsburgh Compound B (PIB). PIB is an analogue of thioflavin- $T$ that, at PET tracer concentrations, binds to fibrillar $A \beta$ deposits with high sensitivity and specificity $[2,3]$. PIB binds to both extracellular amyloid plaques (composed primarily of the A $\beta$ 1-42 peptide $\left.\left(A \beta_{1-42}\right)\right)$ and vascular amyloid deposits (consisting mainly of $A \beta$ 1-40 peptides) [4]. At PET tracer concentrations, PIB does not bind to non-A $\beta$ inclusions such as neurofibrillary tangles or Lewy bodies $[5,6]$ or to brain homogenates from patients with non- $A \beta$ dementia [7].

PIB-PET has rapidly become an integral part of research studies on cognitive aging and the evolution of $\mathrm{AD}$. The 20-minute half-life of ${ }^{11} \mathrm{C}$, however, limits its use to research centers equipped with a cyclotron, and precludes widespread clinical application. More recently, a second generation of amyloid tracers labeled with fluorine-18 $\left({ }^{18} \mathrm{~F}, 110\right.$-minute half-life) has been developed, making it feasible to produce and distribute amyloid tracers for clinical use [8]. Three ${ }^{18} \mathrm{~F}$ amyloid imaging agents are in advanced stages of development: flutemetamol, a 3'-fluoro analog of PIB; florbetapir, a styrylpyridine derivative; and florbetaben, a derivative of stilbene. These tracers have performed comparably with PIB in clinical populations, although nonspecific white matter binding appears to be higher [9-11]. PIB, florbetapir and flutemetamol have been validated prospectively compared with the autopsy diagnosis of $\mathrm{AD}$, and in vivo tracer binding of all three shows high correlation with postmortem measures of fibrillar $\mathrm{A} \beta[3,9,12]$.

In addition to research applications, amyloid imaging has great potential as a diagnostic tool because it directly detects a core feature of the molecular pathology of AD. This stands in contrast to currently available diagnostic imaging techniques in dementia, which detect the downstream effects of pathology on the brain, such as synaptic dysfunction (fluorodeoxyglucose (FDG)-PET) and neuronal 
loss (magnetic resonance imaging (MRI)/computed tomography) - events that are thought to occur late in the disease cascade [13]. Indeed, the clinical utility of amyloid tracers is currently being debated by regulatory agencies [14].

In the present review, we focus on potential clinical applications of amyloid imaging. We summarize the literature on amyloid imaging in a range of neurodegenerative conditions, most of which consists of PIB studies. Data from ${ }^{18} \mathrm{~F}$ tracer studies are presented when available. We restrict our review to tracers that specifically bind to $\mathrm{A} \beta$, and therefore do not discuss fluoro-dicyano-dimethylamino-naphthalenyl propene, a tracer that binds to a number of pathologic inclusions that have an amyloid conformation [15]. We comment on the potential clinical utility of amyloid PET in a variety of clinical scenarios, and provide examples from patients enrolled in a study of amyloid imaging at our institution. Finally, we summarize our recommendations for clinical use of amyloid imaging, and discuss limitations and unresolved questions related to this exciting new technique.

\section{Amyloid PET in various clinical populations Cognitively normal elderly}

Most cognitively healthy normal controls (NC) do not show appreciable amyloid tracer binding (Figure 1). Elevated PIB binding is found in 10 to $30 \%$ of $\mathrm{NC}[16,17]$, however, and this is similar to observed rates of amyloid pathology in autopsy studies of normal aging [18]. In some cases, the extent and distribution of amyloid pathology in $\mathrm{NC}$ is indistinguishable from that found in $\mathrm{AD}$ [19]. Increasing age and the presence of the apolipoprotein E $\varepsilon 4$ allele (ApoE $\varepsilon 4$ ) are the major predictors of PIB-positivity in NC $[17,20]$. Indeed, PIB binding is found in $18 \%$ or less of subjects below the age of 70 , in $26 \%$ of individuals aged 70 to 79 years, and in $30 \%$ of those aged 80 to 89 years. ApoE $\varepsilon 4$ increases the overall prevalence of positive scans from $21 \%$ in noncarriers to $49 \%$ in carriers, and shows dose and age effects. PIBpositivity in NC has also been associated with a family history of $\mathrm{AD}$, and with subjective cognitive impairment $[21,22] .{ }^{18} \mathrm{~F}$ findings in NC have largely been in agreement with PIB findings showing similar prevalence, and relationships with age and ApoE [9-11,23].

The significance of a positive amyloid scan in a cognitively normal individual is uncertain. Some studies have found negative correlations between PIB and episodic memory in this population [16,24], while other studies found no differences across cognitive measures between PIB-positive and PIB-negative controls [25]. More consistently, cross-sectional studies have found AD-like structural and functional brain changes in PIB-positive NC, such as hippocampal and temporo-parietal atrophy $[24,26]$ and decreased resting-state connectivity in the default mode network $[27,28]$. Two retrospective studies reported an association between PIB-positivity and declining cognition $[29,30]$. In the largest prospective cohort, PIB-positivity was associated with declining memory and visuospatial performance [31], and was the strongest predictor of functional decline (conversion from clinical dementia rating of 0 to 0.5 or 1 ) [32]. These cross-sectional and early longitudinal data have strengthened the notion that many (although probably not all) PIB-positive NC are in a preclinical phase of AD [33], but this hypothesis requires further longitudinal investigation.

From a diagnostic perspective, the significant baseline rate of amyloid-positive NC emphasizes that amyloidpositivity is not synonymous with $\mathrm{AD}$, and that amyloid scans cannot be interpreted in lieu of a detailed clinical evaluation. The true baseline rate of amyloid positivity in the general population is difficult to estimate, since current data are based on highly selected convenience cohorts that are probably enriched for AD. Given the strong association between age and PIB, it is likely that the positive predictive value of amyloid PET will be higher in younger patients. At present there is no clinical indication for amyloid imaging in cognitively normal individuals. But this will remain an area of active research in coming years, particularly with the advent of amyloid lowering therapies which might be most effective if initiated in the presymptomatic disease stage [34].

\section{Mild cognitive impairment}

Current data suggest that amyloid imaging provides prognostic information in patients with mild cognitive impairment (MCI), presumably by identifying patients with underlying AD pathology [35,36]. As a group, 52 to $87 \%$ of MCI patients show elevated PIB binding in a similar regional distribution to AD [16,37]. Patients meeting criteria for MCI of the amnestic subtype may be more likely to be PIB-positive than patients with nonamnestic presentations [16]. ${ }^{18} \mathrm{~F}$ tracer studies report similar findings, with positive scans found in 45 to $60 \%$ of MCI patients [10,11,23].

In longitudinal studies, 1-year conversion rates to $\mathrm{AD}$ range from 33 to $47 \%$ in PIB-positive MCI subjects versus virtually no conversions in PIB-negative subjects [38,39]. In the largest longitudinal effort to date [38], authors compared baseline amyloid deposition between MCI converters and nonconverters in 31 MCI subjects followed over 3 years. Overall, 55\% of MCI subjects had increased PIB retention at baseline. The overall conversion rate was $82 \%$ in those with increased PIB uptake, but only $7 \%$ in PIB-negative subjects. Forty-seven per cent of PIB-positive subjects converted within 1 year, and these early converters showed higher tracer retention in the anterior cingulate and frontal cortex than late converters. Altogether, PIB-positive patients with $\mathrm{MCI}$ of the 
amnestic subtype are likely to have early AD, and amyloid imaging will probably have an important role in risk stratification and selection of patients who may benefit from disease-specific therapies.

While amyloid PET is likely to predict whether a patient will convert from $\mathrm{MCI}$ to $\mathrm{AD}$, structural/ functional imaging and cognitive tests may be better predictors of when an individual will convert [40]. This hypothesis is based on a model in which amyloid aggregation is an early event in $\mathrm{AD}$ that reaches a relative plateau even at the MCI stage, while downstream biomarkers measure neuronal loss and dysfunction, and cognitive measures are more dynamic at the symptomatic disease stage [13]. New consensus diagnostic guidelines for MCI make a distinction between biomarkers of $A \beta$ deposition (amyloid PET or cerebrospinal fluid (CSF) $\mathrm{A} \beta_{1-42}$ levels) and biomarkers of neuronal injury (for example, CSF tau, hippocampal/medial temporal atrophy on MRI, hypometabolism on FDG-PET) [41]. Biomarkers from both categories are used in conjunction with core clinical criteria to assess the likelihood that MCI is due to underlying $\mathrm{AD}$. If both $\mathrm{A} \beta$ and neuronal injury markers are positive, a diagnosis of $\mathrm{MCI}$ due to $\mathrm{AD}$-high likelihood can be made. Conversely, if markers from both categories are negative, $\mathrm{MCI}$ is considered unlikely due to $\mathrm{AD}$. If one marker is positive and the other untested, the likelihood of $\mathrm{AD}$ is intermediate - while biomarkers are considered uninformative if they provide conflicting information.

Stratifying MCI patients into those with and without underlying $\mathrm{AD}$ may represent the major clinical use of amyloid imaging. MCI is a common condition, but clinical certainty regarding the underlying histopathology is low (as evidenced by the significant percentage of classical MCI patients of the amnestic subtype who are PIB-negative). As with studies of normal aging, the generalizability of MCI studies based on highly selected research cohorts is questionable because these cohorts are enriched for $\mathrm{AD}$ and often exclude patients with comorbid illnesses that impact cognition (for example, cerebrovascular disease, major organ failure). Amyloid imaging will also be helpful in selecting MCI patients for clinical trials of AD-specific treatments initiated at the predementia state.

\section{Alzheimer's disease and variants}

Most studies have found that PIB-PET has very high $(90 \%$ or greater) sensitivity for $\mathrm{AD}[17,42]$. Tracer binding is diffuse and symmetric, with high uptake consistently found in the prefrontal cortex, precuneus and posterior cingulate cortex, followed closely by the lateral parietal, lateral temporal cortex, and striatum (Figure 1). This pattern closely mirrors the distribution of plaques found at autopsy [43]. Similar to what has been reported in NC and $\mathrm{MCI}$, amyloid aggregation appears to be higher in ApoE $\varepsilon 4$ carriers [44] - although this association is not always found in patients at the dementia stage [45]. Correlations between amyloid load and cognitive measures or disease severity are generally weak or absent $[16,46]$. Longitudinal studies in AD are relatively few and have offered conflicting results, with some studies reporting minimal longitudinal change $[47,48]$ and others reporting average annual increases of up to $5 \%$ in $\mathrm{AD}$ patients [11]. Regardless of whether PIB binding plateaus or continues to increase slowly at the dementia phase, brain atrophy and hypometabolism accelerate at this phase and correlate more robustly with disease severity and clinical progression $[25,46]$.

Few studies have applied amyloid imaging to atypical clinical presentations of $\mathrm{AD}$. One study demonstrated the feasibility of detecting $\mathrm{AD}$ pathology in middle-age persons with Down's syndrome [49]. PIB-PET was used to demonstrate that amyloid deposition is more common in the logopenic variant of primary progressive aphasia (PPA) than in nonfluent or semantic variants [50,51], supporting the hypothesis that the logopenic variant of PPA is predictive of underlying AD. Several studies have detected high PIB binding in patients with posterior cortical atrophy, a visuospatial/biparietal clinical syndrome often caused by AD [52-54]. Although single case reports and small series initially reported atypical binding patterns in PPA and posterior cortical atrophy [55], larger series have found a diffuse binding pattern in these syndromes that is indistinguishable from typical AD and dissociated from the focal structural and metabolic signatures of these syndromes (see PIB and FDG in AD vs. logopenic variant PPA in Figure 1) [50,51,53,54]. Similarly, a study comparing PIB binding in early and late age-of-onset $\mathrm{AD}$ found that differences in cognitive profiles (more global deficits in early-onset AD, and restricted amnesia in late-onset $\mathrm{AD}$ ) could not be explained by the distribution or burden of PIB, which was identical in the two groups [45].

New AD diagnostic guidelines adopt a similar framework to the new MCI guidelines and distinguish between biomarkers of $A \beta$ deposition and neuronal injury [56]. Clinical and biomarker information is used in conjunction to modify the probability of underlying $A D$ pathophysiology. Three main categories are proposed: probable AD dementia, possible AD dementia (atypical clinical presentation), and probable or possible $\mathrm{AD}$ dementia with evidence of AD pathophysiological process. In typical clinical presentations, if both categories of biomarkers are positive, the likelihood of AD pathophysiology is considered high. If only one of the two categories is positive, then the probability is intermediate. Atypical clinical presentations are considered at high probability of an $\mathrm{AD}$ pathophysiological process if both 


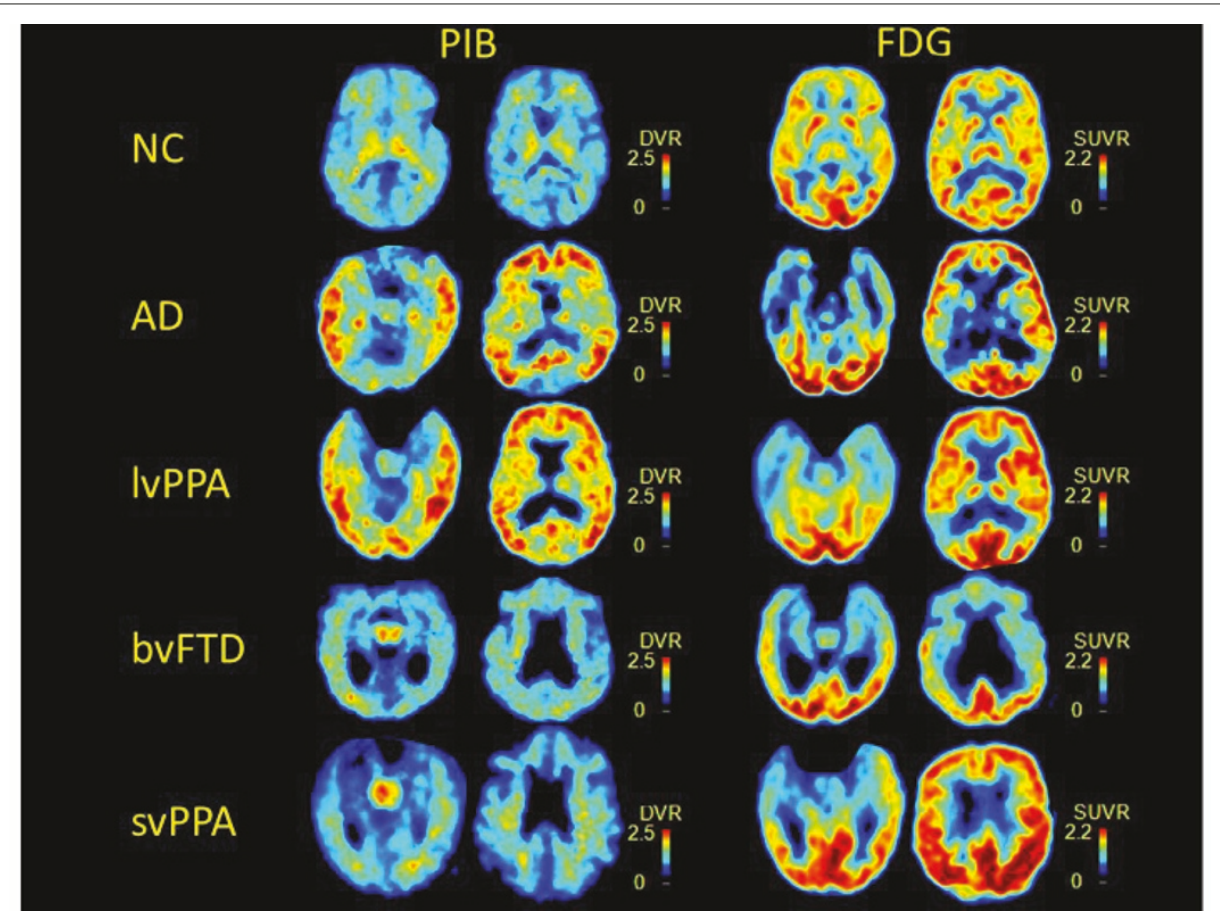

Figure 1. Amyloid tracer binding. Typical " $\mathrm{C}$-labeled Pittsburgh Compound B (PIB) binding and ${ }^{18} \mathrm{~F}$-fluorodeoxyglucose (FDG) hypometabolism patterns in normal controls (NC), Alzheimer's disease (AD), logopenic variant of primary progressive aphasia (IvPPA), behavioral variant frontotemporal dementia (bvFTD), and semantic variant of primary progressive aphasia (sVPPA). DVR, distribution volume ratio; SUVR, standardized uptake value ratio.

categories of biomarkers are positive, although a second etiology cannot be excluded. Finally, dementia is considered unlikely due to $\mathrm{AD}$ when both categories of biomarkers are negative.

Amyloid imaging will probably not add value to the diagnostic work-up of patients with straightforward clinical $\mathrm{AD}$, as these patients are very likely to have positive scans. This technique is likely to be useful in patients with focal cortical syndromes such as PPA and posterior cortical atrophy, as these are pathologically heterogeneous syndromes that are variably associated with underlying AD. Similarly, amyloid PET could be useful in patients with early age-of-onset dementia, as these patients often present with atypical symptoms (for example, executive, behavior, language and visuospatial rather than memory), and the main alternative cause of dementia in this age group is frontotemporal lobar degeneration (FTLD), a non-A $\beta$ disease. The low rate of amyloid-positive nondemented individuals in this age group will increase the positive predictive value of amyloid scans.

\section{Cerebral amyloid angiopathy and vascular dementia}

PIB binds to vascular amyloid deposits in animal models and postmortem human tissue $[2,4,6]$. Nondemented patients with cerebral amyloid angiopathy show high PIB binding compared with controls [57]. Although overall PIB binding is lower than in AD, cerebral amyloid angiopathy patients show a higher occipital-to-global PIB ratio, concordant with the occipital predilection of cerebral amyloid angiopathy at autopsy [58]. PIB may be useful for stratifying patients with microhemorrhages into those with underlying cerebral amyloid angiopathy and those in which hemorrhages are due to small-vessel vasculopathy, particularly when the anatomic distribution of hemorrhages is ambiguous (for example, both lobar and deep gray matter). This distinction may impact decisions regarding anticoagulation. It may also be important to distinguish $\mathrm{AD}$ patients with and without a significant burden of cerebral amyloid angiopathy, as the latter may be at higher risk for complications from amyloid modifying therapies [33]. It is not yet clear whether PIB will be useful for this purpose (for example, based on occipital to global binding ratios) or add value to MRI sequences that are sensitive to microhemorrhages [59].

Vascular dementia can be difficult to differentiate from $\mathrm{AD}$ on clinical grounds [60]. The two share risk factors, are often comorbid, and may interact biologically. Few studies have applied amyloid PET to patients with suspected vascular dementia. One study found that $69 \%$ of patients clinically diagnosed with subcortical vascular 
dementia were PIB-negative [61]. Younger age and a greater number of lacunes predicted a negative PIB scan. Another study found high PIB binding in $40 \%$ of patients with post-stroke dementia [62]. PIB-positive post-stroke patients declined more rapidly on the Mini-Mental State Examination (MMSE) than did PIB-negative patients. Altogether, amyloid PET will probably have a clinical role in identifying cognitively impaired patients with high vascular burden who also have comorbid AD (and thus may benefit from AD treatments), and will further our understanding of how AD and vascular disease interact and contribute to cognitive decline in the aging brain.

\section{Parkinson's disease and dementia with Lewy bodies}

The percentage of PIB-positive scans in patients with dementia with Lewy bodies (DLB) has ranged between 30 and $85 \%$ in small case series [63-67]. Similar variations have been reported in Parkinson's disease dementia (15 to $100 \%$ PIB-positive). PIB scans were negative in two patients with multiple system atrophy [68], and florbetaben-PET was negative in five patients with Parkinson's disease without dementia and positive in $29 \%$ of clinically diagnosed DLB patients [11]. These differences may be explained both by cohort factors and by the method of defining scan positivity (for example, qualitative vs. quantitative, thresholds, and so forth).

The pattern of binding in DLB and Parkinson's disease dementia is similar to $\mathrm{AD}$, although overall binding is lower with higher intersubject variability. Most studies have found higher amyloid plaques in DLB than in Parkinson's disease dementia or nondemented Parkinson's disease patients, and in some studies PIB-positivity was associated with greater cognitive deficits and more rapid disease progression [66]. Overall, these findings are concordant with autopsy-based studies on the frequency and impact of $A \beta$ plaques in DLB and Parkinson's disease dementia [69]. In vitro and postmortem studies suggest that the in vivo PET signal in synuclein disorders reflects PIB binding to $A \beta$ deposits rather than to Lewy bodies $[2,5]$. Given the high frequency of amyloid plaques and generally high rates of positive amyloid scans in DLB, it is unlikely that amyloid PET will be helpful in differentiating DLB from AD. Amyloid PET may differentiate Parkinson's disease or Parkinson's disease dementia from AD, but this differentiation can usually be accomplished clinically. Further work is needed to determine whether amyloid PET can provide prognostic information in synuclein disorders.

\section{Frontotemporal lobar degeneration spectrum disorders}

FTLD is an umbrella term used for disorders associated with neurodegeneration of the frontal and anterior temporal lobes [70]. Clinical syndromes that fall in the FTLD spectrum include the behavioral variant of frontotemporal dementia (bvFTD), frontotemporal dementia with motor-neuron disease, and the semantic and nonfluent variants of PPA [71,72]. Histopathology in FTLD is heterogeneous, with most cases featuring tau (Pick's disease, corticobasal degeneration and progressive supranuclear palsy), TDP-43 or fused-in sarcoma protein inclusions [73]. FTLD and AD are the leading causes of early age-of-onset dementia, occurring with similar frequency in patients presenting younger than the age of 65 [74]. Distinguishing the two during life can be challenging due to clinical and anatomic overlap, and misdiagnosis rates of 10 to $40 \%$ are reported even in expert centers [75].

Differentiating AD from FTLD is an important clinical use for amyloid PET, since $A \beta$ plaques are not part of the FTLD pathologic spectrum, and the differential diagnosis comes up in young patients in whom age-related amyloid aggregation is less common. Small case series reported low rates of PIB (0 to 15\%) and florbetaben-positivity (9\%) in FTLD (see bvFTD and semantic variant PPA in Figure 1) $[11,67,76]$. Differentiating AD and FTLD was the focus of the largest study on the diagnostic utility of amyloid PET published to date [42]. In $62 \mathrm{AD}$ patients and 45 FTLD patients matched for age and disease severity, PIB visual reads had a higher sensitivity for AD than FDG-PET (89.5\% vs. $77.5 \%)$, with similar specificity (83\% vs. $84 \%$ ). When scans were classified quantitatively, PIB had higher sensitivity (89\% vs. 73\%) while FDG had higher specificity (83\% vs. 98\%). PIB outperformed FDG in classifying 12 patients with known histopathology (97\% vs. $87 \%$ overall accuracy). PIB visual reads also showed higher inter-rater reliability and agreement with quantitative classification than FDG, suggesting it was the more accurate and precise technique.

Corticobasal syndrome (CBS) is sometimes included under the FTLD umbrella because of considerable clinical and pathologic overlap [77]. While most cases of clinical CBS are associated with FTLD pathology (although not necessarily corticobasal degeneration), 25 to $50 \%$ of patients are found to have $\mathrm{AD}$ as the causative pathology postmortem [75,77,78]. Amyloid PET would theoretically be useful in identifying CBS patients with underlying $\mathrm{AD}$, but clinical studies are lacking. In our center PIB was positive in a patient with CBS found to have AD/DLB at autopsy (see Figure 2, Case 4), while PIB scans were negative in two CBS patients with pathologically confirmed corticobasal degeneration (unpublished data).

\section{Other conditions}

Clinical symptoms and imaging findings suggestive of normal pressure hydrocephalus (NPH) overlap with those found in neurodegenerative diseases, and AD pathology is found in a significant proportion of patients clinically 


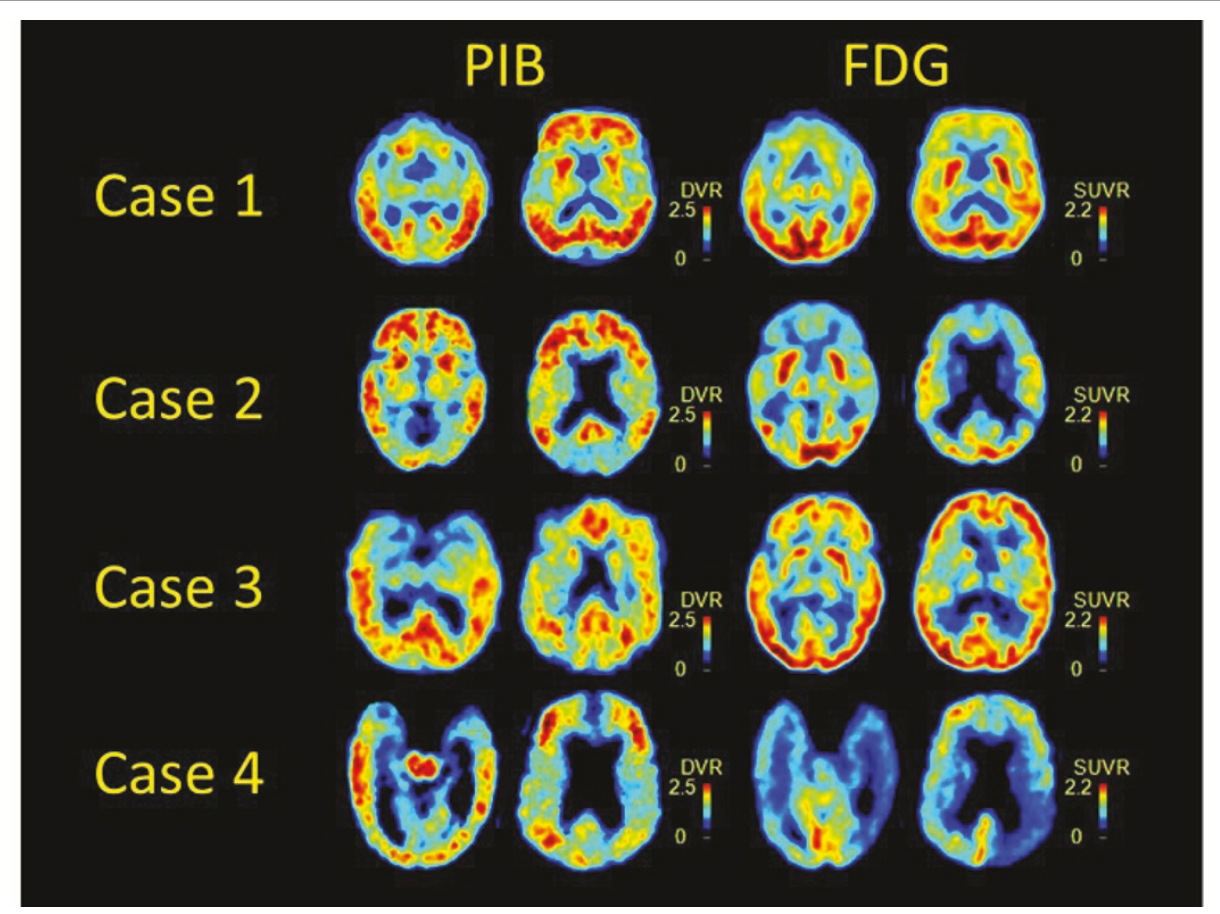

Figure 2. Clinically challenging cases imaged with ${ }^{11} \mathrm{C}$-labeled Pittsburgh Compound B and ${ }^{18} \mathrm{~F}$-fluorodeoxyglucose. Autopsy diagnosis is available in three cases. See text for a description of the cases. FDG, ${ }^{18}$ F-fluorodeoxyglucose; PIB, ${ }^{11}$ carbon-labeled Pittsburgh Compound B; DVR, distribution volume ratio; SUVR, standardized uptake value ratio.

diagnosed with NPH [79]. In some studies, the presence of $\mathrm{AD}$ pathology predicted poor response to shunting [80], prompting a few centers to routinely obtain cortical biopsies prior to shunting suspected NPH [81]. Two studies have compared PIB-PET [81] or flutemetamolPET [12] with frontal biopsy results in patients with suspected NPH. Combined, PET scans were positive in eight out of nine biopsy-positive patients, and negative in eight out of eight biopsy-negative cases. Strong correlations were found between regional tracer uptake and quantitative measures of $A \beta$ in both studies. Further work is needed to determine the prognostic value of amyloid PET in the evaluation of NPH, and to study the proposed biological relationships between AD and NPH [82].

PIB scans were negative in three small series featuring a range of prion disorders, including sporadic CreutzfeldtJakob disease, variant Creutzfeldt-Jakob disease, and a range of prion protein mutations $[83,84]$. Genetic prion disease can occasionally present insidiously and mimic $\mathrm{AD}$, while $\mathrm{DLB}$ can present as a rapidly progressive dementia and be mistaken for Creutzfeldt-Jakob disease. However, prion disease can usually be distinguished from $A \beta$-associated diseases on clinical grounds and based on characteristic MRI findings [85].

A study of PIB in HIV-positive individuals found that cognitively impaired patients with HIV do not show high PIB binding (although some showed low levels of CSF
$\left.\mathrm{A} \beta_{1-42}\right)$, suggesting that PIB may distinguish HIV dementia from AD, a diagnostic dilemma that will become increasingly relevant with an aging HIV-positive population [86].

\section{Amyloid PET applied to clinically challenging cases}

We have applied amyloid and FDG-PET to over 200 patients followed in dementia research cohorts at the University of California San Francisco Memory and Aging Center as part of an ongoing study on the utility of these techniques in differential diagnosis. Figure 2 shows PIB and FDG scans from four clinically challenging cases, described in the vignettes below.

Case 1 is an 89 -year-old man with 8 years of progressive memory loss, executive dysfunction, behavioral changes, and an MMSE of 29. MRI showed severe hippocampal atrophy as well as significant subcortical white matter disease and a number of lacunes. Clinical diagnosis was mixed AD/vascular dementia. FDG showed bifrontal hypometabolism sparing the temporo-parietal cortex, while PIB revealed diffuse cortical binding. Autopsy indicated high-likelihood AD (CERAD frequent/Braak stage 6) and moderate subcortical ischemic vascular disease. In this case, FDG alone could have led to a misdiagnosis of pure vascular disease or bvFTD (the latter less likely based on age), and treatment with a cholinesterase inhibitor may not have been offered. 
Case 2 is a 55 -year-old man with 9 years of profound behavioral changes including compulsive behaviors, disinhibition, socially inappropriate behavior, and impairment in executive, memory, and visuospatial functions (MMSE $=16)$. He was clinically diagnosed with bvFTD. FDG showed bilateral frontal and temporo-parietal hypometabolism, while PIB revealed diffuse cortical binding. Pathology is not available. In this case, PIB provides a useful tiebreaker in favor of AD in an earlyonset dementia patient in whom clinical features and FDG-PET are ambiguous between AD and FTLD. A cholinesterase inhibitor was subsequently started.

Case 3 is a 70-year-old woman presenting with nonfluent variant PPA (MMSE = 28). FDG showed focal left frontal hypometabolism, while PIB was unexpectedly positive. On autopsy the patient was found to have both Pick's disease and high-likelihood AD (CERAD frequent/ Braak 5). This case demonstrates that while PIB can accurately detect AD pathology, a positive amyloid scan does not rule out comorbid non-A $\beta$ pathology, which in this case was FTLD, as predicted based on the clinical presentation and FDG-PET pattern.

Case 4 is a 68-year-old man with 6 years of progressive asymmetric left-sided apraxia, Parkinsonism, dystonia, tremor, and myoclonus. Levodopa treatment was unhelpful. Cognitive decline was characterized by deficits in executive and visuospatial functions, episodic memory and language (MMSE = 19). Visual hallucinations emerged later in the course. Clinical diagnosis was CBS. FDG revealed asymmetric right posterior frontal and temporo-parietal hypometabolism. Pathological diagnosis was mixed high-likelihood AD (CERAD frequent/Braak 6)/ intermediate-likelihood DLB. In this case, PIB correctly predicted underlying $\mathrm{AD}$ in a patient with a clinical syndrome (CBS) associated with varied histopathology.

\section{Amyloid PET in clinical practice: unresolved questions and recommendations}

There are many unknowns that could impact the diagnostic utility of amyloid PET. First, the sensitivity and specificity compared with pathology are not yet well defined. Technical and patient factors that could lead to false positives and false negatives are not clear. PIB binds to both diffuse and neuritic plaques [6] (the latter being more common in normal aging), and the relative contribution of each to the in vivo signal has not been determined. It is not yet clear whether amyloid PET should be interpreted as a dichotomous test (that is, positive versus negative) or whether the degree and spatial distribution of binding offer additional diagnostic information. Studies examining inter-rater and intrarater reliability of visual interpretations are few, and the optimal quantitative threshold for defining a positive scan has not yet been defined [87]. Also not yet established is whether the threshold for PIB-positivity should be adjusted based on demographic factors such as age (as is done when scoring plaques at autopsy) [43] or genetic variables such as the ApoE $\varepsilon 4$ genotype. Significantly, the relationship between amyloid and dementia is weaker in older versus younger individuals [88]. The positive predictive value of a positive amyloid scan in determining the cause of dementia will therefore be lower in older individuals. In general, amyloid PET will be more useful in ruling out (given the high sensitivity for pathology) than in ruling in $\mathrm{AD}$ as the cause of dementia, since the detection of amyloid may be incidental or secondary to a primary, non- $\mathrm{A} \beta$ pathology in some cases (for example, Case 3 above).

The ideal combination of biomarkers in the evaluation of dementia will probably depend on the specific clinical scenario. In general, the approach introduced in the new $\mathrm{AD}$ diagnostic guidelines (one marker specific for $\mathrm{A} \beta$, another specific for neurodegeneration to establish $\mathrm{AD}$ as the probable pathophysiology) has face validity [56]. However, one can imagine that an amyloid scan will add more diagnostic value to a structural image in a 60 year old with an atypical MCI syndrome and hippocampal atrophy (which may or may not be due to AD pathology) than in an 80 year old with clinically classical AD dementia and a clear temporo-parietal cortical atrophy pattern. A number of studies have evaluated the utility of combining amyloid scans with MRI [25] or FDG $[89,90]$, but these analyses have largely been limited to the MCI/ $\mathrm{AD}$ continuum. Also, the relative diagnostic strengths of CSF versus amyloid imaging as molecular markers have yet to be determined. While amyloid tracer binding correlates highly with CSF $A \beta_{1-42}$ levels across the AD continuum [91], how CSF AD biomarkers and amyloid imaging compare in differentiating $\mathrm{AD}$ from other causes of dementia remains to be seen. Initial studies suggest that CSF $A \beta_{1-42}$ may be more sensitive than PIB to early amyloid pathology $[20,92]$, rendering CSF potentially more sensitive for early detection but less specific in determining the cause of dementia. The lack of specificity may be overcome, however, by applying a ratio of Tau/ $A \beta_{1-42}$ or phospho-tau/A $\beta_{1-42}$ [93]. Further head-to-head studies of amyloid PET and CSF are needed to clarify these points. For current practice, we recommend structural neuroimaging as the standard of care for ruling out nondegenerative causes of cognitive decline [94]. A molecular marker (either amyloid PET or CSF) may have added value in particular scenarios, as discussed below. In some clinical scenarios, a nonamyloid molecular tracer may be preferred (for example, dopamine imaging for differentiating AD and DLB) [95].

Ultimately, to be widely adopted a diagnostic test needs to have a significant impact on patient management and outcomes, and to be cost-effective. Few studies have 


\section{Table 1. Clinical and research utility of amyloid imaging}

Potential clinical utility

1. Determine whether $\mathrm{MCl}$ is due to $\mathrm{AD}$

2. Differentiate $A D$ from non-AD dementia (for example, frontotemporal lobar degeneration), particularly in early age-at-onset patients

3. Determine whether AD copathology is present in patients with cognitive impairment and other known neurologic disease (for example, Parkinson's disease, stroke/vascular disease, multiple sclerosis, epilepsy, HIV)

4. Differentiate $\mathrm{AD}$ from nondegenerative cognitive decline (for example, depression, substance abuse)

5. Determine whether $A D$ is present in patients with advanced dementia and no reliable history

6. Identify whether AD is present in focal cortical syndromes (for example, posterior cortical atrophy, primary progressive aphasia, corticobasal syndrome)

7. Differentiate cerebral amyloid angiopathy from intracranial hemorrhage due to small-vessel vasculopathy

Unlikely to have clinical utility

1. Initial investigation of cognitive complaints (in the absence of a detailed neurologic evaluation and cognitive testing)

2. Differentiate AD from other amyloid-beta-associated dementia (for example, dementia with Lewy bodies, cerebral amyloid angiopathy)

3. Differentiate between AD clinical variants (for example, classic amnestic AD vs. posterior cortical atrophy or logopenic variant primary progressive aphasia)

4. Differentiate between non-AD causes of dementia (for example, molecular subtypes of frontotemporal lobar degeneration)

Utility for research only

1. Testing and longitudinal follow-up of asymptomatic or subjective cognitive impairments not meeting $\mathrm{MCl}$ criteria or at-risk individuals (for example, gene mutation carriers, family history of AD, apolipoprotein $\mathrm{E} \varepsilon 4$ allele)

2. Selection of candidates for anti-amyloid treatment trials (AD, MCl, preclinical)

3. Study of the natural evolution of amyloid burden and its role in the pathophysiology of AD and other dementias

4. Potential surrogate marker for anti-amyloid therapies

In all situations, structural imaging using magnetic resonance imaging is recommended to rule out space-occupying lesions, inflammation, or other confounding conditions. AD, Alzheimer's disease; $\mathrm{MCl}$, mild cognitive impairment.

examined these points with regard to amyloid imaging. In our clinic, PIB results have had implications for treatment, mainly affecting decisions about whether to initiate or discontinue $\mathrm{AD}$ symptomatic medications (see case histories). In practice, these medications are probably prescribed to a large number of patients with non-AD dementia, whereas certain populations that may benefit are currently not treated (for example, $\mathrm{MCI}$ due to $\mathrm{AD}$ ) based on negative clinical trials that may have been confounded by biological heterogeneity [96]. Such decisions would be more rational if amyloid PET was applied in the right circumstances, and this could result in cost saving. The more immediate impact of amyloid imaging will be in improving clinical trial design by enrolling patients based on biological, rather than clinical, phenotype. This is a necessary first step for the development and testing of disease-specific therapies. Initial studies have found that requiring a positive molecular biomarker for inclusion will render AD clinical trials more efficient and less costly, especially in early disease stages [97]. In fact, a positive amyloid scan may be the primary inclusion criterion for a study focused on AD prevention.

Recommendations for potential clinical applications of amyloid PET are provided in Table 1 . These applications are based on our analysis of the data and our institutional experience, and represent an early attempt to guide clinicians in how to apply amyloid PET to their practice. The recommendations were formulated using the following principles: amyloid PET cannot be interpreted in the absence of clinical context (as is the case with any diagnostic test); amyloid PET will be most useful in differentiating $A \beta$ from non- $A \beta$ causes of dementia in scenarios in which this distinction is clinically challenging - these scenarios might include patients with mild symptoms (for example, MCI), cases presenting with pathologically heterogeneous clinical syndromes (for example, PPA, CBS), patients with early age-of-onset dementia, or cases with symptoms that could be explained by either $A \beta$ processes or nondegenerative causes (for example, NPH, intracranial microhemorrhages); and, finally, some very important applications of amyloid PET should be restricted to research studies (for example, scanning asymptomatic or minimally symptomatic patients).

\section{Conclusions}

While amyloid imaging has produced an impressive body of research in a short time, studies of practical clinical applications for this technology lag far behind studies with more biological objectives. Since clinical use is now feasible and will probably be approved by regulatory agencies in the near future, it is imperative that the diagnostic performance, added clinical value, and costeffectiveness of this technique be studied systematically 
and in populations more representative of real clinical practice. With all its limitations, amyloid imaging represents a major breakthrough in the evaluation of dementia that will doubtlessly translate into better clinical care, and will ultimately help guide the development of molecular-based therapies for these devastating illnesses.

This article is part of a review series on Amyloid Imaging.

Other articles in the series can be found online at

http://alzres.com/series/amyloidimaging

\section{Abbreviations}

$A \beta$, amyloid beta; $A \beta_{1-42}$ amyloid beta 1-42 peptide; $A D$, Alzheimer's disease; ApoE $\varepsilon 4$, apolipoprotein E \&4 allele; bvFTD, behavioral variant of frontotemporal dementia; ${ }^{1} \mathrm{C}$, carbon-11; CBS, corticobasal syndrome; CERAD, Consortium to Establish a Registry for Alzheimer's Disease; CSF, cerebrospinal fluid; DLB, dementia with Lewy bodies; ${ }^{18}$, fluorine-18; FDG, fluorodeoxyglucose; FTLD, frontotemporal lobar degeneration; $\mathrm{MCI}$ mild cognitive impairment; MMSE, Mini-Mental State Examination; MRI, magnetic resonance imaging; $\mathrm{NC}$, normal controls; $\mathrm{NPH}$, normal pressure hydrocephalus; PIB, Pittsburgh Compound B; PET, positron emission tomography; PPA, primary progressive aphasia.

\section{Competing interests}

RL Jr declares that he has no competing interests. GDR received consulting fees from GE Healthcare, and receives grant support from Avid radiopharmaceuticals, a wholly-owned subsidiary of Eli Lilly and Company. Both companies are developing amyloid PET tracers for commercial purposes.

\section{Acknowledgements}

The authors would like to thank DrWJ Jagust and Dr S Villeneuve for their review of the manuscript prior to publication. GDR is supported by grants from the National Institute on Aging (K23-AG031861) and the John Douglas French Alzheimer's Foundation.

Published: 10 November 2011

\section{References}

1. Klunk WE, Engler H, Nordberg A, Wang Y, Blomqvist G, Holt DP, Bergström $M$, Savitcheva I, Huang GF, Estrada S, Ausén B, Debnath ML, Barletta J, Price JC, Sandell J, Lopresti BJ, Wall A, Koivisto P, Antoni G, Mathis CA, Långström B: Imaging brain amyloid in Alzheimer's disease with Pittsburgh Compound-B. Ann Neurol 2004, 55:306-319.

2. Bacskai BJ, Frosch MP, Freeman SH, Raymond SB, Augustinack JC, Johnson KA, Irizarry MC, Klunk WE, Mathis CA, Dekosky ST, Greenberg SM, Hyman BT, Growdon JH: Molecular imaging with Pittsburgh Compound B confirmed at autopsy: a case report. Arch Neurol 2007, 64:431-434

3. Ikonomovic MD, Klunk WE, Abrahamson EE, Mathis CA, Price JC, Tsopelas ND, Lopresti BJ, Ziolko S, Bi W, Paljug WR, Debnath ML, Hope CE, Isanski BA, Hamilton RL, DeKosky ST: Postmortem correlates of in vivo PiB-PET amyloid imaging in a typical case of Alzheimer's disease. Brain 2008, 131:1630-1645.

4. Bacskai BJ, Hickey GA, Skoch J, Kajdasz ST, Wang Y, Huang GF, Mathis CA, Klunk WE, Hyman BT: Four-dimensional multiphoton imaging of brain entry, amyloid binding, and clearance of an amyloid-beta ligand in transgenic mice. Proc Natl Acad Sci U S A 2003, 100:12462-12467.

5. Fodero-Tavoletti MT, Smith DP, McLean CA, Adlard PA, Barnham KJ, Foster LE, Leone L, Perez K, Cortés M, Culvenor JG, Li QX, Laughton KM, Rowe CC, Masters CL, Cappai R, Villemagne VL: In vitro characterization of Pittsburgh Compound-B binding to Lewy bodies. J Neurosci 2007, 27:10365-10371.

6. Lockhart A, Lamb JR, Osredkar T, Sue LI, Joyce JN, Ye L, Libri V, Leppert D, Beach TG: PIB is a non-specific imaging marker of A peptide-related cerebral amyloidosis. Brain 2007, 130:2607-2615

7. Klunk WE, Wang Y, Huang GF, Debnath ML, Holt DP, Shao L, Hamilton RL, Ikonomovic MD, DeKosky ST, Mathis CA: The binding of 2-(4'-methylaminophenyl)benzothiazole to post-mortem brain homogenates is dominated by the amyloid component. J Neurosci 2003, 23:2086-2092.
8. Jagust WJ: Amyloid imaging: coming to a PET scanner near you. Ann Neurol 2010, 68:277-278.

9. Clark CM, Schneider JA, Bedell BJ, Beach TG, Bilker WB, Mintun MA, Pontecorvo MJ, Hefti F, Carpenter AP, Flitter ML, Krautkramer MJ, Kung HF, Coleman RE, Doraiswamy PM, Fleisher AS, Sabbagh MN, Sadowsky CH, Reiman EP, Zehntner SP, Skovronsky DM: Use of florbetapir-PET for imaging $\beta$-amyloid pathology. JAMA 2011, 305:275-283.

10. Fleisher AS, Chen K, Liu X, Roontiva A, Thiyyagura P, Ayutyanont N, Joshi AD, Clark CM, Mintun MA, Pontecorvo MJ, Doraiswamy PM, Johnson KA Skovronsky DM, Reiman EM: Using positron emission tomography and florbetapir $\mathrm{F} 18$ to image cortical amyloid in patients with mild cognitive impairment or dementia Due to Alzheimer disease. Arch Neurol 2011. [Epub ahed of print]

11. Villemagne VL, Ong K, Mulligan RS: Amyloid imaging with ${ }^{18} \mathrm{~F}$-florbetaben in Alzheimer disease and other dementias. J Nucl Med 2011, 52:1210-1217.

12. Wolk DA, Grachev ID, Buckley C, Kazi H, Grady MS, Trojanowski JQ, Hamilton RH, Sherwin P, McLain R, Arnold SE: Association between in vivo fluorine 18-labeled flutemetamol amyloid positron emission tomography imaging and in vivo cerebral cortical histopathology. Arch Neurol 2011. [Epub ahead of print]

13. Jack CR Jr, Knopman DS, Jagust WJ, Shaw LM, Aisen PS, Weiner MW, Petersen RC, Trojanowski JQ: Hypothetical model of dynamic biomarkers of the Alzheimer's pathological cascade. Lancet Neurol 2010, 9:119-128.

14. Alzheimer Research Forum [http://www.alzforum.org/new/detail. asp?id=2667]

15. Small GW, Kepe V, Ercoli LM, Siddarth P, Bookheimer SY, Miller KJ, Lavretsky H, Burggren AC, Cole GM, Vinters HV, Thompson PM, Huang SC, Satyamurthy N, Phelps ME, Barrio JR: PET of brain amyloid and tau in mild cognitive impairment. N Engl J Med 2006, 355:2652-2663.

16. Pike KE, Savage G, Villemagne VL, Ng S, Moss SA, Maruff P, Mathis CA, Klunk WE, Masters CL, Rowe CC: Amyloid imaging and memory in non-demented individuals: evidence for preclinical Alzheimer's disease. Brain 2007, 130:2837-2844.

17. Rowe CC, Ellis KA, Rimajova M, Bourgeat P, Pike KE, Jones G, Fripp J, TochonDanguy H, Morandeau L, O'Keefe G, Price R, Raniga P, Robins P, Acosta O, Lenzo N, Szoeke C, Salvado O, Head R, Martins R, Masters CL, Ames D, Villemagne $\mathrm{VL}$ : Amyloid imaging results from the Australian Imaging, Biomarkers and Lifestyle (AIBL) study of aging. Neurobiol Aging 2010, 31:1275-1283.

18. Knopman DS, Parisi JE, Salviati A, Floriach-Robert M, Boeve BF, Ivnik RJ, Smith GE, Dickson DW, Johnson KA, Petersen LE, McDonald WC, Braak H, Petersen RC: Neuropathology of cognitively normal elderly. J Neuropathol Exp Neurol 2003, 62:1087-1095.

19. Mintun MA, Larossa GN, Sheline YI, Dence CS, Lee SY, Mach RH, Klunk WE, Mathis CA, DeKosky ST, Morris JC: [" $\left.{ }^{11} \mathrm{C}\right] \mathrm{PIB}$ in a nondemented population: potential antecedent marker of Alzheimer disease. Neurology 2006, 67:446-452.

20. Morris JC, Roe CM, Xiong C, Fagan AM, Goate AM, Holtzman DM, Mintun MA: APOE predicts amyloid- $\beta$ but not tau Alzheimer pathology in cognitively normal aging. Ann Neurol 2010, 67:122-131.

21. Chételat G, Villemagne VL, Bourgeat P, Pike KE, Jones $G$, Ames D, Ellis KA, Szoeke C, Martins RN, O'Keefe GJ, Salvado O, Masters CL, Rowe CC Relationship between atrophy and $\beta$-amyloid deposition in Alzheimer disease. Ann Neurol 2010, 67:317-324.

22. Mosconi L, Rinne JO, Tsui WH, Berti V, Li Y, Wang H, Murray J, Scheinin N, Någren K, Williams S, Glodzik L, De Santi S, Vallabhajosula S, de Leon MJ: Increased fibrillar amyloid- $\beta$ burden in normal individuals with a family history of late-onset Alzheimer's. Proc Natl Acad Sci U S A 2010, 107:5949-5954.

23. Vandenberghe R, Van Laere K, Ivanoiu A, Salmon E, Bastin C, Triau E, Hasselbalch S, Law I, Andersen A, Korner A, Minthon L, Garraux G, Nelissen N Bormans G, Buckley C, Owenius R, Thurfell L, Farrar G, Brooks DJ: ${ }^{18} \mathrm{~F}$-flutemetamol amyloid imaging in Alzheimer disease and mild cognitive impairment: a phase 2 trial. Ann Neurol 2010, 68:319-329.

24. Mormino EC, Kluth JT, Madison CM, Rabinovici GD, Baker SL, Miller BL, Koeppe RA, Mathis CA, Weiner MW, Jagust WJ: Episodic memory loss is related to hippocampal mediated $\beta$-amyloid deposition in elderly subjects. Brain 2009, 132:1310-1323.

25. Jack CR Jr, Lowe VJ, Senjem ML, Weigand SD, Kemp BJ, Shiung MM, Knopman DS, Boeve BF, Klunk WE, Mathis CA, Petersen RC: "1C $\mathrm{CiB}$ and structural MRI provide complementary information in imaging of Alzheimer's disease 
and amnestic mild cognitive impairment. Brain 2008, 131:665-680.

26. Dickerson BC, Bakkour A, Salat DH, Feczko E, Pacheco J, Greve DN, Grodstein F, Wright Cl, Blacker D, Rosas HD, Sperling RA, Atri A, Growdon JH, Hyman BT, Morris JC, Fischl B, Buckner RL: The cortical signature of Alzheimer's disease: regionally specific cortical thinning relates to symptom severity in very mild to mild AD dementia and is detectable in asymptomatic amyloidpositive individuals. Cereb Cortex 2009, 19:497-510.

27. Hedden T, Van Dijk KR, Becker JA, Mehta A, Sperling RA, Johnson KA, Buckne $\mathrm{RL}$ : Disruption of functional connectivity in clinically normal older adults harboring amyloid burden. J Neurosci 2009, 29:12686-12694.

28. Mormino EC, Smiljic A, Hayenga AO, Onami SH, Greicius MD, Rabinovici GD, Janabi M, Baker SL, Yen IV, Madison CM, Miller BL, Jagust WJ: Relationships between $\beta$-amyloid and functional connectivity in different components of the default mode network in aging. Cereb Cortex 2011, 21:2399-2407.

29. Resnick SM, Sojkova J, Zhou Y, An Y, Ye W, Holt DP, Dannals RF, Mathis CA, KlunkWE, Ferrucci L, Kraut MA, Wong DF: Longitudinal cognitive decline is associated with fibrillar amyloid-beta measured by $\left[{ }^{11} \mathrm{C}\right] \mathrm{PiB}$. Neurology 2010, 74:807-815

30. Villemagne VL, Pike KE, Darby D, Maruff P, Savage G, Ng S, Ackermann U, Cowie TF, Currie J, Chan SG, Jones G, Tochon-Danguy H, O'Keefe G, Masters $C L$, Rowe $C C$ : $A \beta$ deposits in older non-demented individuals with cognitive decline are indicative of preclinical Alzheimer's disease. Neuropsychologia 2008, 46:1688-1697.

31. Storandt M, Mintun MA, Head D, Morris JC: Cognitive decline and brain volume loss as signatures of cerebral amyloid-beta peptide deposition identified with Pittsburgh Compound B: cognitive decline associated with A $\beta$ deposition. Arch Neurol 2009, 66:1476-1481.

32. Morris JC, Roe CM, Grant EA, Head D, Storandt M, Goate AM, Fagan AM, Holtzman DM, Mintun MA: Pittsburgh Compound B imaging and prediction of progression from cognitive normality to symptomatic Alzheimer disease. Arch Neurol 2009, 66:1469-1475.

33. Sperling RA, Jack CR Jr, Black SE, Frosch MP, Greenberg SM, Hyman BT, Scheltens P, Carrillo MC, Thies W, Bednar MM, Black RS, Brashear HR, Grundman M, Siemers ER, Feldman HH, Schindler RJ: Amyloid-related imaging abnormalities in amyloid-modifying therapeutic trials: recommendations from the Alzheimer's Association Research Roundtable Workgroup. Alzheimers Dement 2011, 7:367-385.

34. Hyman BT: Amyloid-dependent and amyloid-independent stages of Alzheimer disease. Arch Neurol 2011, 68:1062-1064.

35. Pontecorvo MJ, Mintun MA: PET amyloid imaging as a tool for early diagnosis and identifying patients at risk for progression to Alzheimer's disease. Alzheimer's Res Ther 2011, 3:11.

36. Rabinovici, GD, Jagust, WJ: Amyloid imaging in aging and dementia: testing the amyloid hypothesis in vivo. Behav Neuro/ 2009, 21:117-128.

37. Kemppainen NM, Aalto S, Wilson IA, Någren K, Helin S, Brück A, Oikonen V Kailajärvi M, Scheinin M, Viitanen M, Parkkola R, Rinne JO: PET amyloid ligand $\left[{ }^{11} \mathrm{C}\right] \mathrm{PIB}$ uptake is increased in mild cognitive impairment. Neurology 2007 68:1603-1606

38. Okello A, Koivunen J, Edison P, Archer HA, Turkheimer FE, Någren K, Bullock R, Walker Z, Kennedy A, Fox NC, Rossor MN, Rinne JO, Brooks DJ: Conversion of amyloid positive and negative $\mathrm{MCI}$ to $\mathrm{AD}$ over 3 years: an ${ }^{11} \mathrm{C}$-PIB PET study. Neurology 2009, 73:754-760.

39. Wolk DA, Price JC, Saxton JA, Snitz BE, James JA, Lopez OL, Aizenstein HJ, Cohen AD, Weissfeld LA, Mathis CA, Klunk WE, De-Kosky ST: Amyloid imaging in mild cognitive impairment subtypes. Ann Neurol 2009, 65:557-568.

40. Jack CR Jr, Wiste HJ, Vemuri P, Weigand SD, Senjem ML, Zeng G, Bernstein MA, Gunter JL, Pankratz VS, Aisen PS, Weiner MW, Petersen RC, Shaw LM, Trojanowski JQ, Knopman DS: Brain $\beta$-amyloid measures and magnetic resonance imaging atrophy both predict time-to-progression from mild cognitive impairment to Alzheimer's disease. Brain 2010, 133:3336-3348.

41. Albert MS, DeKosky ST, Dickson D, Dubois B, Feldman HH, Fox NC, Gamst A, Holtzman DM, Jagust WJ, Petersen RC, Snyder PJ, Carrillo MC, Thies B, Phelps $\mathrm{CH}$ : The diagnosis of mild cognitive impairment due to Alzheimer's disease: recommendations from the National Institute on AgingAlzheimer's Association workgroups on diagnostic guidelines for Alzheimer's disease. Alzheimers Dement 2011, 7:270-279.

42. Rabinovici GD, Rosen HJ, Alkalay A, Kornak J, Furst AJ, Agarwal N, Mormino EC, O'Neil JP, Janabi M, Karydas A, Growdon ME, Jang JY, Huang EJ, DeArmond SJ, Trojanowski JQ, Grinberg LT, Gorno-Tempini ML, Seeley WW, Miller BL, Jagust WJ: Amyloid versus FDG PET in the differential diagnosis of $A D$ and FTLD. Neurology, in press.
43. Braak E, Griffing K, Arai K, Bohl J, Bratzke H, Braak H: Neuropathology of Alzheimer's disease: what is new since A. Alzheimer? Eur Arch Psychiatry Clin Neurosci 1999, 249:14-22

44. Grimmer T, Tholen $S$, Yousefi BH, Alexopoulos $P$, Förschler A, Förstl H, Henriksen G, Klunk WE, Mathis CA, Perneczky R, Sorg C, Kurz A, Drzezga A: Progression of cerebral amyloid load is associated with the apolipoprotein E ع4 genotype in Alzheimer's disease. Biol Psychiatry 2010, 68:879-884.

45. Rabinovici GD, Furst AJ, Alkalay A, Racine CA, O'Neil JP, Janabi M, Baker SL, Agarwal N, Bonasera SJ, Mormino EC, Weiner MW, Gorno-Tempini ML, Rosen HJ, Miller BL, Jagust WJ: Increased metabolic vulnerability in early-onset Alzheimer's disease is not related to amyloid burden. Brain 2010, 133:512-528.

46. Furst AJ, Rabinovici GD, Rostomian AH, Steed T, Alkalay A, Racine C, Miller BL, Jagust WJ: Cognition, glucose metabolism and amyloid burden in Alzheimer's disease. Neurobiol Aging 2010. [Epub ahead of print]

47. Engler H, Forsberg A, Almkvist O, Blomquist G, Larsson E, Savitcheva I, Wall A, Ringheim A, Långström B, Nordberg A: Two-year follow-up of amyloid deposition in patients with Alzheimer's disease. Brain 2006, 129:2856-2866.

48. Jack CR Jr, Lowe VJ, Weigand SD, Wiste HJ, Senjem ML, Knopman DS, Shiung MM, Gunter JL, Boeve BF, Kemp BJ, Weiner M, Petersen RC: Serial PIB and MRI in normal, mild cognitive impairment and Alzheimer's disease: implications for sequence of pathological events in Alzheimer's disease. Brain 2009, 132:1355-1365.

49. Landt J, D'Abrera JC, Holland AJ, Aigbirhio FI, Fryer TD, Canales R, Hong YT, Menon DK, Baron JC, Zaman SH: Using positron emission tomography and carbon 11-labeled Pittsburgh Compound B to image brain fibrillar $\beta$-amyloid in adults with Down syndrome: safety, acceptability, and feasibility. Arch Neuro/ 2011, 68:890-896.

50. Rabinovici GD, Jagust WJ, Furst AJ, Ogar JM, Racine CA, Mormino EC, O'Neil JP, Lal RA, Dronkers NF, Miller BL, Gorno-Tempini ML: A $\beta$ amyloid and glucose metabolism in three variants of primary progressive aphasia. Ann Neurol 2008, 64:388-401.

51. Leyton CE, Villemagne VL, Savage S, Pike KE, Ballard KJ, Piquet O, Burrell JR, Rowe CC, Hodges JR: Subtypes of progressive aphasia: application of the international consensus criteria and validation using $\beta$-amyloid imaging. Brain 2011, 134:3030-3043.

52. Formaglio M, Costes N, Seguin J, Tholance Y, Le Bars D, Roullet-Solignac I, Mercier B, Krolak-Salmon P, Vighetto A: In vivo demonstration of amyloid burden in posterior cortical atrophy: a case series with PET and CSF findings. J Neuro/ 2011, 258:1841-1851.

53. Rosenbloom MH, Alkalay A, Agarwal N, Baker SL, O'Neil JP, Janabi M, Yen IV Growdon M, Jang J, Madison C, Mormino EC, Rosen HJ, Gorno-Tempini ML, Weiner MW, Miller BL, Jagust WJ, Rabinovici GD: Distinct clinical and metabolic deficits in PCA and AD are not related to amyloid distribution. Neurology 2011, 76:1789-1796

54. de Souza LC, Corlier F, Habert MO, Uspenskaya O, Maroy R, Lamari F, Chupin M, Lehéricy S, Colliot O, Hahn-Barma V, Samri D, Dubois B, Bottlaender M Sarazin M: Similar amyloid- $\beta$ burden in posterior cortical atrophy and Alzheimer's disease. Brain 2011, 134:2036-2043.

55. Ng SY, Villemagne VL, Masters CL, Rowe CC: Evaluating atypical dementia syndromes using positron emission tomography with carbon 11-labeled Pittsburgh Compound B. Arch Neurol 2007, 64:1140-1144.

56. McKhann GM, Knopman DS, Chertkow H, Hyman BT, Jack CR Jr, Kawas CH, Klunk WE, Koroshetz WJ, Manly JJ, Mayeux R, Mohs RC, Morris JC, Rossor MN, Scheltens P, Carrillo MC, Thies B, Weintraub S, Phelps CH: The diagnosis of dementia due to Alzheimer's disease: recommendations from the National Institute on Aging-Alzheimer's Association workgroups on diagnostic guidelines for Alzheimer's disease. Alzheimers Dement 2011, 7:263-269.

57. Johnson KA, Gregas M, Becker JA, Kinnecom C, Salat DH, Moran EK, Smith EE, Rosand J, Rentz DM, Klunk WE, Mathis CA, Price JC, Dekosky ST, Fischman AJ, Greenberg SM: Imaging of amyloid burden and distribution in cerebral amyloid angiopathy. Ann Neurol 2007, 62:229-234.

58. LLy JV, Donnan GA, Villemagne VL, Zavala JA, Ma H, O'Keefe G, Gong SJ, Gunawan RM, Saunder T, Ackerman U, Tochon-Danguy H, Churilov L, Phan TG, Rowe CC: ${ }^{11} \mathrm{C}-\mathrm{PIB}$ binding is increased in patients with cerebral amyloid angiopathy-related haemorrhage. Neurology 2010, 74:487-493.

59. Maxwell SS, Jackson CA, Paternoster L, Cordonnier C, Thijs V, Al-Shahi Salman R, Sudlow CL: Genetic associations with brain microbleeds: systematic review and meta-analyses. Neurology 2011, 77:158-167.

60. Chui HC, Zarow C, Mack WJ, Ellis WG, Zheng L, Jagust WJ, Mungas D, Reed BR, Kramer JH, Decarli CC, Weiner MW, Vinters HV: Cognitive impact of 
subcortical vascular and Alzheimer's disease pathology. Ann Neurol 2006, 60:677-687.

61. Lee JH, Kim SH, Kim GH, Seo SW, Park HK, Oh SJ, Kim JS, Cheong HK, Na DL: Identification of pure subcortical vascular dementia using ${ }^{11} \mathrm{C}-$-Pittsburgh Compound B. Neurology 2011, 77:18-25.

62. Mok V, Leung EY, Chu W, Chen S, Wong A, Xiong Y, Lam W, Ho CL, Wong KS: Pittsburgh Compound B binding in poststroke dementia. J Neurol Sci 2010, 290:135-137.

63. Edison P, Rowe CC, Rinne JO, Ng S, Ahmed I, Kemppainen N, Villemagne VL, O'Keefe G, Någren K, Chaudhury KR, Masters CL, Brooks DJ: Amyloid load in Parkinson's disease dementia and Lewy body dementia measured with $\left[{ }^{11} \mathrm{C}\right]$ PIB positron emission tomography. J Neurol Neurosurg Psychiatry 2008, 79:1331-1338

64. Foster ER, Campbell MC, Burack MA, Hartlein J, Flores HP, Cairns NJ, Hershey T, Perlmutter JS: Amyloid imaging of Lewy body-associated disorders. Mov Disord 2010, 25:2516-2523.

65. Gomperts SN, Rentz DM, Moran E, Becker JA, Locascio JJ, Klunk WE, Mathis CA, Elmaleh DR, Shoup T, Fischman AJ, Hyman BT, Growdon JH, Johnson KA: Imaging amyloid deposition in Lewy body diseases. Neurology 2008, 71:903-910.

66. Maetzler W, Liepelt I, Reimold M, Reischl G, Solbach C, Becker C, Schulte C, Leyhe T, Keller S, Melms A, Gasser T, Berg D: Cortical PIB binding in Lewy body disease is associated with Alzheimer-like characteristics. Neurobiol Dis 2009, 34:107-112

67. Rowe CC, Ng S, Ackermann U, Gong SJ, Pike K, Savage G, Cowie TF, Dickinson KL, Maruff P, Darby D, Smith C, Woodward M, Merory J, Tochon-Danguy H, O'Keefe G, Klunk WE, Mathis CA, Price JC, Masters CL, Villemagne VL: Imaging $\beta$-amyloid burden in aging and dementia. Neurology 2007, 68:1718-1725.

68. Claassen DO, Lowe VJ, Peller PJ, Petersen RC, Josephs KA: Amyloid and glucose imaging in dementia with Lewy bodies and multiple systems atrophy. Parkinsonism Relat Disord 2011, 17:160-165.

69. Ballard C, Ziabreva I, Perry R, Larsen JP, O'Brien J, McKeith I, Perry E, Aarsland D: Differences in neuropathologic characteristics across the Lewy body dementia spectrum. Neurology 2006, 67:1931-1934.

70. Rabinovici GD, Miller BL: Frontotemporal lobar degeneration: epidemiology, pathophysiology, diagnosis and management. CNS Drugs 2010, 24:375-398.

71. Gorno-Tempini ML, Hillis AE, Weintraub S, Kertesz A, Mendez M, Cappa SF, Ogar JM, Rohrer JD, Black S, Boeve BF, Manes F, Dronkers NF, Vandenberghe R, Rascovsky K, Patterson K, Miller BL, Knopman DS, Hodges JR, Mesulam MM, Grossman M: Classification of primary progressive aphasia and its variants. Neurology 2011, 76:1006-1014.

72. Neary D, Snowden JS, Gustafson L, Passant U, Stuss D, Black S, Freedman M, Kertesz A, Robert PH, Albert M, Boone K, Miller BL, Cummings J, Benson DF: Frontotemporal lobar degeneration: a consensus on clinical diagnostic criteria. Neurology 1998, 51:1546-1554

73. Mackenzie IR, Neumann M, Bigio EH, Cairns NJ, Alafuzoff I, Kril J, Kovacs GG, Ghetti B, Halliday G, Holm IE, Ince PG, Kamphorst W, Revesz T, Rozemuller AJ, Kumar-Singh S, Akiyama H, Baborie A, Spina S, Dickson DW, Trojanowski JQ, Mann DM: Nomenclature and nosology for neuropathologic subtypes of frontotemporal lobar degeneration: an update. Acta Neuropathol 2010, 119:1-4.

74. Ratnavalli E, Brayne C, Dawson K, Hodges JR: The prevalence of frontotemporal dementia. Neurology 2002, 58:1615-1621.

75. Alladi S, Xuereb J, Bak T, Nestor P, Knibb J, Patterson K, Hodges JR: Focal cortical presentations of Alzheimer's disease. Brain 2007, 130:2636-2645

76. Rabinovici GD, Furst AJ, O'Neil JP, Racine CA, Mormino EC, Baker SL, Chetty S, Patel P, Pagliaro TA, Klunk WE, Mathis CA, Rosen HJ, Miller BL, Jagust WJ: ${ }^{11} \mathrm{C}-\mathrm{PIB}$ PET imaging in Alzheimer disease and frontotemporal lobar degeneration. Neurology 2007, 68:1205-1212.

77. Lee SE, Rabinovici GD, Mayo MC: Clinicopathological correlations in corticobasal degeneration. Ann Neurol 2011, 70:327-340.

78. Ling H, O'Sullivan SS, Holton JL, Revesz T, Massey LA, Williams DR, Paviour DC, Lees AJ: Does corticobasal degeneration exist? A clinicopathological re-evaluation. Brain 2010, 133:2045-2057.

79. Golomb J, Wisoff J, Miller DC, Boksay I, Kluger A, Weiner H, Salton J, Graves W: Alzheimer's disease comorbidity in normal pressure hydrocephalus: prevalence and shunt response. J Neurol Neurosurg Psychiatry 2000, 68:778-781.

80. Hamilton R, Patel S, Lee EB, Jackson EM, Lopinto J, Arnold SE, Clark CM, Basil A Shaw LM, Xie SX, Grady MS, Trojanowski JQ: Lack of shunt response in suspected idiopathic normal pressure hydrocephalus with Alzheimer disease pathology. Ann Neurol 2010, 68:535-540.

81. Leinonen V, Alafuzoff I, Aalto S, Suotunen T, Savolainen S, Någren K, Tapiola T, Pirttilä T, Rinne J, Jääskeläinen JE, Soininen H, Rinne JO: Assessment of $\beta$-amyloid in a frontal cortical brain biopsy specimen and by positron emission tomography with carbon 11-labeled Pittsburgh Compound B. Arch Neurol 2008, 65:1304-1319.

82. Silverberg GD, Mayo M, Saul T, Rubenstein E, McGuire D: Alzheimer's disease, normal-pressure hydrocephalus, and senescent changes in CSF circulatory physiology: a hypothesis. Lancet Neurol 2003, 2:506-511.

83. Hyare H, Ramlackhansingh A, Gelosa G, Edison P, Rudge P, Brandner S, Brooks DJ, Collinge J, Mead S: "'C-PiB PET does not detect PrP-amyloid in prion disease patients including variant Creutzfeldt-Jakob disease. J Neurol Neurosurg Psychiatry 2011. [Epub ahead of print]

84. Boxer AL, Rabinovici GD, Kepe V, Goldman J, Furst AJ, Huang SC, Baker SL, O'neil JP, Chui H, Geschwind MD, Small GW, Barrio JR, Jagust W, Miller BL: Amyloid imaging in distinguishing atypical prion disease from Alzheimer disease. Neurology 2007, 69:283-290.

85. Geschwind MD, Shu H, Haman A, Sejvar JJ, Miller BL: Rapidly progressive dementia. Ann Neurol 2008, 64:97-108.

86. Ances BM, Benzinger TL, Christensen JJ, Thomas J, Venkat R, Teshome M, Aldea P, Fagan AM, Holtzman DM, Morris JC: HIV associated neurocognitive disorder (HAND) is not associated with increased fibrillar amyloid deposits using 11C-PiB in middle-aged HIV+ participants. Arch Neurol, in press.

87. Mormino EC, Brandel MG, Madison CM, Rabinovici GD, Marks S, Baker SL, Jagust WJ: Not quite PIB-positive, not quite PIB-negative: slight PIB elevations in elderly normal control subjects are biologically relevant. Neuroimage 2011. [Epub ahead of print]

88. Savva GM, Wharton SB, Ince PG, Forster G, Matthews FE, Brayne C: Age, neuropathology, and dementia. N Eng/ J Med 2009, 360:2302-2309.

89. Li Y, Rinne JO, Mosconi L, Pirraglia E, Rusinek H, DeSanti S, Kemppainen N, Någren K, Kim BC, Tsui W, de Leon MJ: Regional analysis of FDG and PIB-PET images in normal aging, mild cognitive impairment, and Alzheimer's disease. Eur J Nucl Med Mol Imaging 2008, 35:2169-2181.

90. Devanand DP, Mikhno A, Pelton GH, Cuasay K, Pradhaban G, Dileep Kumar JS, Upton N, Lai R, Gunn RN, Libri V, Liu X, van Heertum R, Mann JJ, Parsey RV: Pittsburgh Compound B ( $\left({ }^{11} \mathrm{C}-\mathrm{PIB}\right)$ and fluorodeoxyglucose $\left({ }^{18} \mathrm{~F}-\mathrm{FDG}\right) \mathrm{PET}$ in patients with Alzheimer disease, mild cognitive impairment, and healthy controls. J Geriatr Psychiatry Neurol 2010, 23:185-198.

91. Jagust WJ, Landau SM, Shaw LM, Trojanowski JQ, Koeppe RA, Reiman EM, Foster NL, Petersen RC, Weiner MW, Price JC, Mathis CA: Relationships between biomarkers in aging and dementia. Neurology 2009, 73:1 193-1199.

92. Cairns NJ, Ikonomovic MD, Benzinger T, Storandt M, Fagan AM, Shah AR, Reinwald LT, Carter D, Felton A, Holtzman DM, Mintun MA, Klunk WE, Morris $J C$ : Absence of Plttsburgh Compound B detection of cerebral amyloid beta in a patient with clinical, cognitive, and cerebrospinal fluid markers of Alzheimer disease. Arch Neurol 2009, 66:1557-1562.

93. Shaw LM, Vanderstichele H, Knapik-Czajka M, Clark CM, Aisen PS, Petersen RC, Blennow K, Soares H, Simon A, Lewczuk P, Dean R, Siemers E, Potter W, Lee VM, Trojanowski JQ: Cerebrospinal fluid biomarker signature in Alzheimer's Disease Neuroimaging Initiative subjects. Ann Neurol 2009, 65:403-413.

94. Knopman DS, DeKosky ST, Cummings JL, Chui H, Corey-Bloom J, Relkin N, Small GW, Miller B, Stevens JC: Practice parameter: diagnosis of dementia (an evidence-based review). Report of the Quality Standards Subcommittee of the American Academy of Neurology. Neurology 2001, 56:1143-1153.

95. Burke JF, Albin RL, Koeppe RA, Giordani B, Kilbourn MR, Gilman S, Frey KA: Assessment of mild dementia with amyloid and dopamine terminal positron emission tomography. Brain 2011, 134:1647-1657.

96. Petersen RC, Thomas RG, Grundman M, Bennett D, Doody R, Ferris S, Galasko D, Jin S, Kaye J, Levey A, Pfeiffer E, Sano M, van Dyck CH, Thal LJ: Vitamin E and donepezil for the treatment of mild cognitive impairment. NEng/ J Med 2005, 352:2379-2388.

97. van Rossum IA, Vos S, Handels R, Visser PJ: Biomarkers as predictors for conversion from mild cognitive impairment to Alzheimer-type dementia: implications for trial design. J Alzheimers Dis 2010, 20:881-891.

doi:10.1186/alzrt93

Cite this article as: Laforce $R \mathrm{Jr}$, Rabinovici GD: Amyloid imaging in the differential diagnosis of dementia: review and potential clinical applications. Alzheimer's Research \& Therapy 2011, 3:31. 